\title{
Problems and Prospects of Curbside Parking in Lahore: PolicyImplications for Effective Management
}

\author{
SALMAN SABIR*, AND GHULAM ABBAS ANJUM** \\ RECEIVED ON 12.05.2016 ACCEPTED ON 22.11.2016
}

\begin{abstract}
Lahore is a fast-growing metropolis experiencing rapid growth in people and vehicle population. This unprecedented growth has led to urban sprawl, dependency on motorized transport, and increased parking space demands throughout the city limits. Off-street parking supply is insufficient and the demand is met mainly by roadside parking with and without any authorization. Parking on the roads and sidewalks has resulted in reduction in traffic capacity, traffic speed variation, accidents and disruption in smooth flow of traffic. Though the government has adopted measures in the past to streamline roadside parking activities, these efforts have proved counter-productive. This paper provides a critical analysis of the existing parking situation in Lahore based on detailed surveys and interviews. It presents an assessment of the functional performance of selected parking sites located at various roads. The findings not only provide significant evidence of the problems caused by haphazard curbside parking but also highlight its prospects if managed properly. The paper argues that absence of by-laws governing curbside parking, weak institutions, and inadequate public transport are the main causes of prevailing parking crisis. It concludes that development of curbside parking regulations in line with urban transport policy is a first step towards managing existing and future curbside parking resources in Lahore.
\end{abstract}

Key Words: Curbside Parking, Parking Management, Traffic Management, Public Transport.

\section{INTRODUCTION}

$\mathrm{W}$ ith rapid increase in private transport modes, the menace of curbside parking has clung to several metropolitan cities across the world. In order to seriously cope with this situation, many cities have employed a number of techniques and strategies to manage curbside parking using geometry, timing, pricing, technology and enforcement. Cities namely Redwood and Pasadena, California have successfully gained control over curbside parking spaces with the help of market-based variable pricing techniques
[1-2].A critical review of the literature on this subject reveals a completely different picture. For example, some researchers favor curbside parking as it provides convenience, encourages shared use of space, acts as safety buffer for pedestrians, and occupies less space than off-street lots [3-4].There are experts who oppose parking on the roads because it causes traffic congestion, traffic crashes, and environmental pollution [3-6]. However, a paper by Marshall et. al. [3] discusses both positive as well as negative points of curbside parking.

Corresponding Author (E-Mail: salmansabir@hotmail.com)

* Department of City \& Regional Planning, University of Engineering \& Technology, Lahore.

** $\quad$ Faculty of Architecture \& Planning, University of Engineering \& Technology, Lahore.

Mehran University Research Journal of Engineering \& Technology, Volume 36, No. 4, October, 2017 [p-ISSN: 0254-7821, e-ISSN: 2413-7219] 
The city of Lahore, Pakistan is also experiencing mismanaged curbside parking proliferation. The urban roads and streets of the city originally meant to carry traffic flow have started to facilitate huge volumes of parked vehicles. This phenomenon is taking place in the city both with and without approval of civic agencies.

This paper attempts to provide a critical analysis of curbside parking practices in Lahore. It not only discusses the nature and extent of problems associated with curbside parking but also deliberates on its implicit prospects.

The methodology covers primary and secondary data collected under a research study on curbside parking management in Lahore [7].The secondary data used, in the mentioned study, includes number of authorized parking sites, number of registered vehicles, related maps, and reports, etc. However, information on primary aspects was collected through reconnaissance survey, profile development survey, traffic count survey, structured interviews with drivers, traffic wardens, contractors, and concerned government officials using questionnaires and interview checklists developed for this purpose. Out of the total authorized parking sites recorded during the survey, nine different cases were selected for detailed analysis on the basis of cluster sampling technique. Using this method, a well-defined selection criteria was developed revolving around parameters such as: geographical location (central or non-central), degree of problems (less or more), parking provision (cars or motorcycles or both), regulatory authority (CDGL (City District Government Lahore) or TMA (Town Municipal Administration)), location or position (carriageway or service road) and topology (single-sided or double-sided). At the time of the survey, carefully calculated sample size of six percent was picked from the population keeping in mind the set criteria and intention that curbside parking occurrence in every different form must be reflected in detailed investigation. In order to measure the traffic impact, traffic count survey was conducted in peak hour at those parking sites which were operational on carriageways of busy roads. The traffic count values were later converted into measurable PCUs (Passenger Car Units). The collected information was updated with respect to the total number of authorized parking sites. The data analysis was carried out mainly using SPSS and Microsoft Excel.

\section{PARKING SITUATION IN LAHORE}

\subsection{Population and Spatial Growth}

Lahore is the provincial capital of Punjab and the second largest city of Pakistan. According to 1998 census report, the population of Lahore Metropolitan Area was 6.94 million [8]. A study's estimates, however, show that the city has touched the population of ten million at an annual growth rate of 3\% [9].Lahore is not fully planned like Islamabad but it represents a combination of planned and unplanned areas. The unplanned areas in Lahore (consisting of old establishments) are mostly concentrated in and around the center of the city whereas, the planned areas (including residential housing schemes) are located far away from the inner urban core.

Due to the absence of any zoning regulations, the commercial land uses have spread all over the city in an unorganized manner. The city has also witnessed linear commercialization of land use alongside its busy roads and streets. This commercialization trend has not only allowed low-dense commercial activities but also facilitated high-density commercial buildings. For instance, Ali [10] highlights that the development speed of high-rise commercial activities accelerated four-years ago when a number of multi-storey commercial buildings sprouted along several major roads. He further describes that most of the high-rise/multi-storey development lacks provision of adequate parking spaces and consequently, parking comes on the roads in the vicinity. 


\subsection{Motor Vehicular Growth}

With tremendous increase in population and rising prosperity, motorized traffic has significantly increased over the past few years. Table 1 and Fig. 1 show traffic growth, based on total number of registered vehicles per year from 2008-2012, using data compiled by Excise and Taxation Department, Government of the Punjab, Lahore.The registered vehicles include motorcycles, cars and other modes of traffic (such as pick-ups, tractors, trolleys, trucks, wagons, AC buses, bus, excavators, rickshaws, etc). Motorcycles were the fastest growing travel mode with an estimated average increase of $14 \%$ per year and had the largest mode share with almost $60 \%$ of all traffic. Motorcycles continue increasing because their lower prices as compared to cars are easier for people to afford. Similar to motorcycles, cars grew an average of 8.3\% annually; however, they handle only half the traffic of motorcycles with a share of $27 \%$.

Compared to other transport modes, cars and motorcycles contribute significantly to overall traffic. Both require parking space not only at the origin but also at the destination. Therefore, this explosion in vehicle growth requires a serious solution.

\subsection{Urban Public Transport}

Lahore's public transport system consists of bus and taxi services. The public and private operators provide multiple types of bus services, including private buses and mini-buses. However, taxi services — rickshaws and Qingqis (motorcycle rickshaw) — are provided only by private operators. Despite the new 27km long BRT (Bus Rapid Transit) service, Lahore's transit system is stillnot as modern or comprehensive as cities in developed and even some less developed countries. Moreover, the overall share of public transport is relatively low. There are several reasons why Lahorites do not prefer public transport: high traveling costs, deficient routes, less supply corresponding to demand, poor performance, inefficient operation, and limited and poor condition of facilities (including terminals and buses) [9]. In the absence of a well-managed public transport system, people use their private transport modes (especially motorcycles and cars) to cater to their day to day needs of commuting.

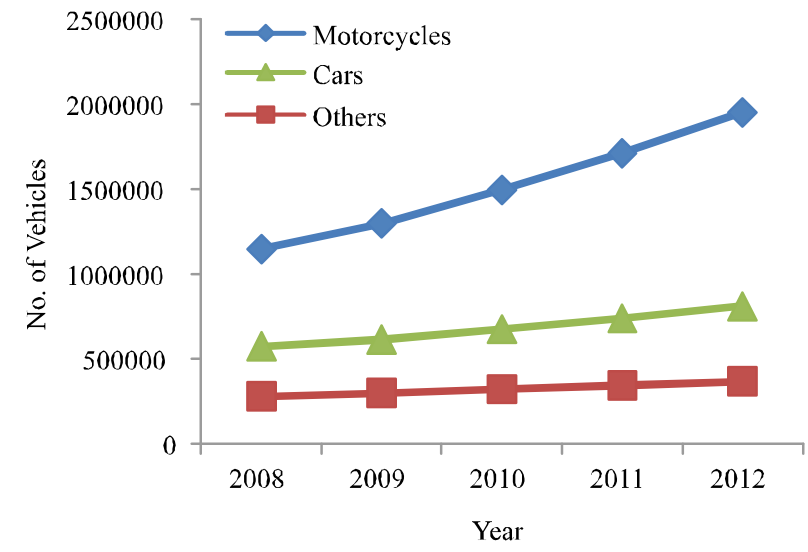

FIG. 1. SHOWING TRAFFIC GROWTH PATTERN IN LAHORE 2008-2012

TABLE 1. SHOWING TRAFFIC GROWTH IN LAHORE (2008-2012)

\begin{tabular}{|c|c|c|c|c|c|c|c|c|c|c|}
\hline \multirow{3}{*}{ Vehicles } & \multicolumn{10}{|c|}{ Year } \\
\hline & \multicolumn{2}{|c|}{2008} & \multicolumn{2}{|l|}{2009} & \multicolumn{2}{|c|}{2010} & \multicolumn{2}{|c|}{2011} & \multicolumn{2}{|c|}{2012} \\
\hline & No. & $\%$ & No. & $\%$ & No & $\%$ & No & $\%$ & No & $\%$ \\
\hline Motorcycles & $1,147,999$ & 57 & $1,297,942$ & 59 & $1,496,572$ & 60 & $1,712,076$ & 61 & $1,951,714$ & 62 \\
\hline Cars & 573,340 & 29 & 613,504 & 28 & 674,668 & 27 & 739,104 & 26 & 810,289 & 26 \\
\hline Others & 279,219 & 14 & 298,683 & 13 & 321,743 & 13 & 344,448 & 12 & 367,434 & 12 \\
\hline Total & $2,000,558$ & 100 & $2,210,129$ & 100 & $2,492,983$ & 100 & 2,795,628 & 100 & $3,129,437$ & 100 \\
\hline
\end{tabular}

Mehran University Research Journal of Engineering \& Technology, Volume 36, No. 4, October, 2017 [p-ISSN: 0254-7821, e-ISSN: 2413-7219] 


\subsection{Parking Provision}

The existing parking demand in Lahore is met by numerous parking practices which include off-street covered parking, frontage parking, parking plazas, parking lots, and curbside parking. The following sub-sections provide the theoretical understanding of each category.

\subsubsection{Off-Street Covered Parking}

This refers to parking spaces earmarked in buildings in accordance with space standards laid down in the applicable building regulations. Planning agencies in Lahore do not approve building plans until the parking space requirement is fulfilled. For example, [11] specifies parking requirements with respect to various building types (residential, commercial, offices, public buildings, etc.), as shown in Table 2.

It is observed by the researchers that most of the builders earmark parking spaces in the buildings in order to get their plans approved. During the construction phase, they utilize such spaces for other activities(such as shops)just to increase their saleable area. Therefore, when the building is complete, fewer spaces are built than the spaces mentioned in the approved plans. The TEPA (Traffic Engineering and Transportation Planning Agency), which is responsible to ensure the availability of parking spaces, takes least interest due to its inadequate capacity.

TABLE 2. LISTED PARKING SPACE STANDARDS [11]

\begin{tabular}{|c|c|c|c|}
\hline \multirow{2}{*}{ No. } & \multirow{2}{*}{ Type of Building } & \multicolumn{2}{|c|}{ Parking Standard } \\
\hline & & Car Space Requirement & Motorcycle Space Requirement \\
\hline 1. & Apartment & $\begin{array}{l}1 \text { car space for every } 1200 \text { sqft of covered } \\
\text { area subject to a minimum of one car space } \\
\text { for every housing unit }\end{array}$ & \multirow{12}{*}{$\begin{array}{l}16 \% \text { of the total car parking area shall be } \\
\text { reserved for motorcycles. }\end{array}$} \\
\hline 2. & $\begin{array}{l}\text { Offices, Commercial including large stores \& } \\
\text { Retail Shops, Hospitals \& Exhibition Halls }\end{array}$ & 1 car space for every 1000 sqft of floor area & \\
\hline \multirow{4}{*}{3.} & \multirow{4}{*}{ Hotels } & 1 car space for every 6 rooms & \\
\hline & & $\begin{array}{l}1 \text { car space for every 800sq ft of shopping } \\
\text { area }\end{array}$ & \\
\hline & & 1 car space for every 1000 sqft of office area & \\
\hline & & 1 car space for every 500 sqft of floor area & \\
\hline 4. & Restaurants, Clubs \& Cafes & 1 car space for every 500 sqft of floor area & \\
\hline 5. & $\begin{array}{l}\text { Marriage Halls, Banquet Halls \& } \\
\text { Community Centers }\end{array}$ & 1 car space for every 500 sqft of floor area & \\
\hline 6. & Cinema, Theatres \& Concert Halls & 1 car space for every 5 seats & \\
\hline 7. & Post Office \& Police Station & 1 car space for every 2000 sqft of floor area & \\
\hline \multirow{2}{*}{8.} & \multirow{2}{*}{ Industrial Buildings and Warehouses } & $\begin{array}{c}1 \text { car space for every } 500 \text { sqftof floor area of } \\
\text { the administrative block }\end{array}$ & \\
\hline & & $\begin{array}{l}1 \text { car space for every } 2000 \text { sqft of floor area } \\
\text { for the workers }\end{array}$ & \\
\hline 9. & School, Colleges and Educational Institutions & 1 car space for every 2000 sqft of floor area & $\begin{array}{l}40 \% \text { of car parking shall be reserved for } \\
\text { motorcycles }\end{array}$ \\
\hline
\end{tabular}

Mehran University Research Journal of Engineering \& Technology, Volume 36, No. 4, October, 2017 [p-ISSN: 0254-7821, e-ISSN: 2413-7219] 


\subsubsection{Frontage Parking}

This parking type is operational in Lahore in the past several years and is mainly related to the concept of commercialization of residential properties. Commercialization refers to conversion of residential plot/ property into non-residential use which is purely against the approved housing scheme or master plan of a city. A number of roads and streets were declared as 'commercial' in the city along which permanent commercial activity was allowed. However, to legally change land uses, the properties had to comply with Lahore's parking space standards and front setback requirements. These requirements forced property owners to accommodate parked cars in the building's setback, with modifications based on plot size and adjacent right-of-ways.

\subsubsection{Parking Plazas}

In high-density commercial areas of the city where vacant land is non-existent, the practice of constructing multistorey parking plazas has been a norm. D-Point Parking Plaza in Shah AlamMarket, andLDA Parking Plaza in Liberty Market are highly relevant examples of this parking type. The Government of the Punjab through TEPA has also planned to construct new parking plazas near predominant commercial areas in Lahore [9].

TEPA has also constructed a Park-and-Ride facility along Main Boulevard near Liberty Market. At the time of planning, it was decided that the public transport system would be connected with this park and ride plaza; thus far, transit connectivity is stilllackingeven after its construction. Drivers pay to parkat D-Point and the Parkand-Ride facility whereas LDA Parking Plaza offers free parking.

\subsubsection{Parking Lots}

Unlike already discussed practices, small and large-scale parking lots are common in various planned commercial areas in Lahore. These parking lots are usually off-street, open parking areas, which not only provideparking spaces, but also includeother related features like landscaping, parking islands, and vehicle circulation spaces (aisle and access lanes). Liberty Parking Lot in Gulberg Town, Fortress Stadium Parking Lot in Cantonment area, andMoon-Market Parking Lot in Iqbal Town are few examples of this concept and all three lots charge for parking.

\section{CURBSIDE PARKING}

Curbside parking means parking spaces along the sides of the road, whether in parallel or in diagonal to the curb configurations. This is the most commonly-observed form of parking in the metropolitan city of Lahore. It not only exists along public roads, streets and sidewalks but also along one or both edges of service roads.

In order to control the occurrence of curbside parking, CDGL has declared 32 roads sections where parking is permitted in the form of small scale stands. These parking stands cater to the needs of cars as well as motorcycles parking. TMAs have also declared some parking spots authorized within their jurisdictions on roads other than those declared by CDGL for parking purposes. A related study demonstrates that $20 \%$ of Lahore's $2000 \mathrm{~km}$ network of primary, secondary and tertiary roads is used by curbside parking [9] (Fig. 2). However, Fig. 2 only includes the locations of the 359 authorized parking sites in Lahore as per data collected from Le-Park in May 2013, whereas the locations of unauthorized parking sites are not known due to unavailability of the official record.

In 2009, CDGL experimented with managing curbside parking at the Panorama Shopping Centre (also known as PnD Zone-2) by installing pay-and-display parking meter. Parking rates started at PKR 10/- (US\$0.10) for the first hour and then PKR 5/- for every subsequent hour. Longerterm parking rates included a daily rate of PKR 50

Mehran University Research Journal of Engineering \& Technology, Volume 36, No. 4, October, 2017 [p-ISSN: 0254-7821, e-ISSN: 2413-7219] 
(PKR 20/- for shopkeepers and traders) and a weekly rate of PKR 200/-. Illegal parking incurred fines up to PKR 500/-. To help citizens with the new meters, CDGL setup an information center near Masjid-e-Shohdaa [12].

Unfortunately, the pay-and-display meters experienced some growing pains. First, the parking locations lacked adequate staff to monitor parking violations. Second, drivers were not familiar with the system and did not support charging-by-the-hour. Third, parking contractors were against the meter scheme because fully-autonomous machines did not allow overcharging. Fourth, businessmen were against the meters as irritated drivers went elsewhere, causing a slump in customers and retail sales for nearby businesses.

To resolve these problems, CDGL has established the Lahore Parking Company (Le-Park) based on ISPARK model of Istanbul, Turkey. It has assigned Le-Park withan

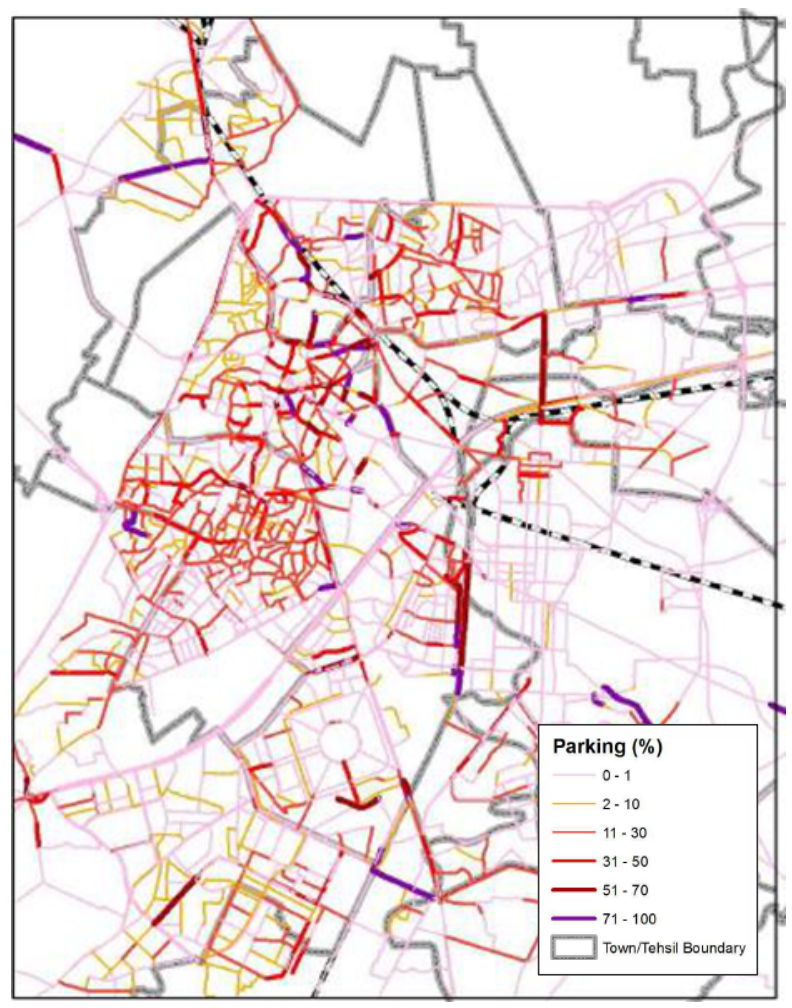

FIG. 2. DISTRIBUTION OF CURBSIDE PARKING IN LAHORE [9] exclusive task of planning and development of new parking facilities, as well as the management, control, and operation of existing public and private parking facilities in Lahore.

Interviews with CDGL officials reveal that roads were selected to allow curbside parking without considering any reasonable criteria or feasibility study. The main reason for this lack of scrutiny involves no proper guidelines being available for curbside parking management. The only criteria used for selecting a road for curbside parking is the quantity of existing unauthorized curbside parking spots. This is quite similar to declaring a road as commercialized based on the occurrence of existing illegal conversions from residential to commercial land use. In other words, this situation reflects CDGL's weak enforcement capacity in allowing illegal parking to occur in the first place.

Although CDGL analyzed aspects like available road space, road type, and traffic levels when considering toallow curbside parking, it has not yet carried out any detailed surveys and investigations to provide guidance. According to[9], the authorities provided parking facilities without giving due diligence to the effect of traffic demand on junctions, service roads and main carriageways. In fact, traffic wardens interviewed told that curbside parking sites such as Warid Office (Empress Road) and SNGPL office (Gurumanget Road) are authorized adjacent to U-turns, hindering the turning movement of buses and other large vehicles. Officials also informed that exact dimensions of parking stands are not marked at multiple sites, causing illegal expansion of the parking space dimensions.

Efficient parking planning and control is the result of coordination among various departments, which unfortunately is non-existent in Lahore. Civic agencies grant approval of curbside parking spaces in an isolated

Mehran University Research Journal of Engineering \& Technology, Volume 36, No. 4, October, 2017 [p-ISSN: 0254-7821, e-ISSN: 2413-7219] 
manner, without consulting related departments like traffic police, building control agencies, and public transport companies. For instance, Khan [13]] , for example, notes that traffic wardens often take serious actions against parking spaces causing traffic congestion by fully removing or reducing the space used of parked vehicles. In fact, traffic wardens often do not even inquire about the approval of parking spaces from parking attendants before taking any action. This situation truly reflects the wide communication gap among several departments when it comes to curbside parking management, thus contributing to the parking chaos.

The mismanagement of curbside parking in Lahore is the result of incapacitated institutions responsible for parking management. They are lacking in terms of resources, manpower and expertise to effectively streamline parking resources. As a result of institutional incapacity, enormous growth of unauthorized parking stands has occurred along important roads of the city. In most cases, concerned officials try to take actions against such unauthorized parking stands, but the "parking mafia," backed by influential people, do not allow such actions. For instance, Husnain [14] reports that most of the illegal parking sites are located in Gulberg Town, Samanabad Town, and Data Ganj Baksh Town, backed by highly influential people and trade union activists. He further argues that owners of adjoining commercial establishments use spaces in front of their plazas as free parking and concerned authorities cannot take action against them. In order to collect maximum revenue from these so-called "free parking spaces," the owners contract these spaces out to private contractors; since the spaces are not legally registered, CDGL cannot collect the resulting revenue.

Although CDGL and TMAs have issued legal status to a number of parking sites with the condition of charging legally-determined parking rates, parking contractors often charge twice these rates. With an eye towards earning maximum profit, they not only use the additional traffic lanes for parking purposes, but also use adjacent sidewalks for parked cars, hindering pedestrian movement. NESPAK [15] describes the situation:

"Issue of roadside parking is purely a management problem on the part of City District Government Lahore. Firstly, because it is being treated as revenue generating activity (as being practiced by Ex-MCL) and therefore most of the roads have been contracted out to collect maximum fee from the on-street parker. Private contractors, in pursuit of collecting maximum revenue, manage for maximum parking irrespective of availability of parking space and capacity of road for normal movement of traffic" [15].

\section{PROBLEMS OF CURBSIDE PARKING}

This section discusses the key problems associated with curbside parking. The detail of each problem is discussed in the following sub-sections.

\subsection{Irrational Parking Tariff}

Before 2008, the legally-established parking rates were PKR.10/- and PKR. 5/- for cars and motorcycles, respectively. Yet since 2008, these parking rates have doubled to PKR20/- and PKR 10/- respectively. Unfortunately, this fixed parking fee set by the department is irrational. For instance, an interview with officials reveals that the price has been set without considering any detailed research studies. Instead of encouraging high customer turnover, the current prices encourage longer parking duration and less turnover of parking spaces [7].

\subsection{Reduction in Carrying Capacity of Roads}

As previously described, curbside parking spaces may create traffic congestion in normal traffic flows, but is

Mehran University Research Journal of Engineering \& Technology, Volume 36, No. 4, October, 2017 [p-ISSN: 0254-7821, e-ISSN: 2413-7219] 
especially likely during the peak hours. Though a number of factors are attributed to traffic congestion, the presence of poorly parked vehicles plays pivotal role in hindering traffic flow. The traffic impact of curbside parking spots was studied along selected carriageway sites in Lahore, based on two scenarios: “with” and “"without” curbside parking (Figs. 3-4).

The analysis showed that carriageways could absorb 35\% more traffic volume on average as a result of removing curbside parking. An overwhelming majority of drivers (48\%) reported that reduction in road capacity was the main problem resulting curbside parking. A similar study [5] analyzes the reduction in road capacity due to parked vehicles along the curb. He describes that the reduction in carrying capacity of roads occurs due to the decrease in carriageway width and the frictional effectof parking activity with moving traffic streams.Additionally,Sisiopiko [4] supports the argument that curbside parking affects road capacity.

\subsection{Traffic Speed Reduction}

Curbside parking also causes significant reduction in the speed of moving traffic. The survey results show that a large majority of drivers (72\%) agreed about the possibility of speed reduction due to curbside parking. Of these drivers, 41\% believed the average speed reduction ranged from 11-15 kilometers per hour, 26\% observed speed reduction within 5-10 kilometers per hour, whereas 5\% responded with 'more than 15 kilometers per hour' speed reduction. To study the aspect of traffic speed reduction from different perspectives, the viewpoint of drivers was taken in 'before' and 'after' parking cases. Drivers' response, in the former case,tells us that they wait for a safe gap in the traffic flow, which helps them to leave their parking spaces and merge with flowing traffic. However, drivers, in the latter case, first reduce traffic speed when they intend to parkand then look for parking. An author mentioned. Shoup [16], in his influential book The High Cost of Free Parking, observes that reduction is traffic speed is caused by entering and leaving of vehicles in spaces not just the appearance of a parked vehicle. He also notes that the value of average speed reduction was equivalent to14\% [16].

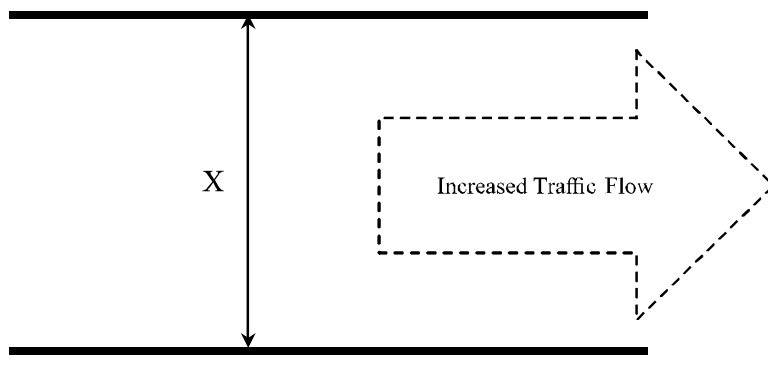

$\mathrm{ZX} /(\mathrm{X}-\mathrm{Y})=$ traffic volume passing through the effective carriageway width $(\mathrm{X})$

FIG. 4. TRAFFIC FLOW IN ABSENCE OF CURBSIDE PARKING

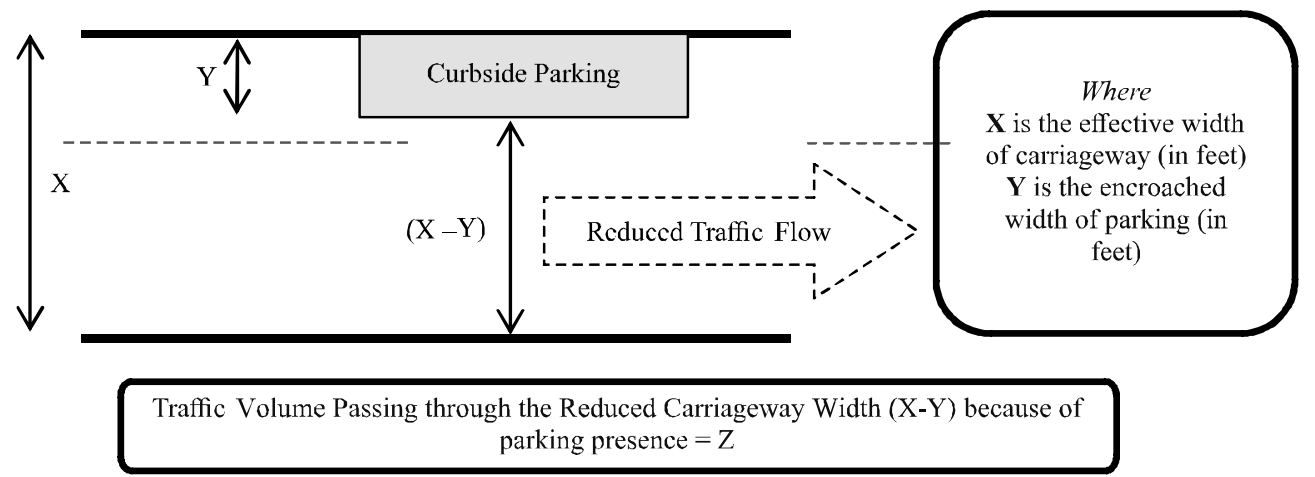

FIG. 3. TRAFFIC FLOW IN PRESENCE OF CURBSIDE PARKING

Mehran University Research Journal of Engineering \& Technology, Volume 36, No. 4, October, 2017 [p-ISSN: 0254-7821, e-ISSN: 2413-7219] 


\section{PROSPECTS OF CURBSIDE PARKING}

A complete picture of curbside parking cannot be presented if its advantages are overlooked. Following sub-sections therefore discuss the key prospects provided by curbside parking.

\subsection{Parking Supply}

With parking demand increasing greatly in various areas of Lahore, curbside parking plays an important role in meeting this demand by increasing parking supply. A research study shown Sabir [7] found that selected parking sites in Lahore, on average, contributed enough additional parking spaces for up to 18 cars and 43 motorcycles.

As of March 2013, 359 parking sites are authorized by LePark. We estimated the total number of parking spaces contributed by these parking sites by multiplying the amount of average parking spaces per site with the total number of registered curbside parking sites in Lahore. The results are presented in Table 3, which shows that the 359 authorized parking sites provide parking spaces for around 6,500 cars and 15,500 motorcycles.
Nonetheless, we believe this is a conservative estimate due to the large number of unauthorized parking sites.

\subsection{Revenue Generation}

One of the main prospects of curbside parking is economic gains, one reason why the government is eager to regulate it. In order to estimate the economic benefits of curbside parking, we used Sabir [7] data to learn about the average parking revenue per site. The average revenue was then multiplied with the total authorized parking sitesin order to obtain the net revenue. Table 4 shows that an estimated PKR 414 million per year are earned out of registered parking sitesby the government although even more revenue can be generated if the unauthorized parking sites are registered and regulated.

\subsection{Less Land Consumption}

Curbside parking is considered to use less land space in comparison with off-street parking lots. According to the LDA Building and Zoning Regulations, a car requires a parking space of 128 , or 176 square feet including maneuvering space. However, if the same space is

TABLE 3. CONTRIBUTION OF CURBSIDE PARKING IN REGULAR PARKING SUPPLY [7]

\begin{tabular}{|c|c|c|c|}
\hline \multirow{2}{*}{ No. } & Name of Curbside Parking Site & Parking Spaces \\
\cline { 3 - 4 } & Ufone\& HBL Office Davis Road & 13 & Motorcycles \\
\hline 1. & Warid Office Empress Road & NA & 35 \\
\hline 2. & SNGPL Office Gurumanget Road & NA & 85 \\
\hline 3. & MacDonald Model Town Link Road & 12 & 15 \\
\hline 4. & Mobile Zone Gulberg & 10 & 80 \\
\hline 5. & Hafeez Center Main Boulevard & 16 & NA \\
\hline 6. & Eden Heights Jail Road & 18 & 65 \\
\hline 7. & Warid Office Main Boulevard & 35 & 20 \\
\hline 8. & New AurigaComplex Main Boulevard & 25 & 43 \\
\hline 9. & Average Parking Spaces in 9 parking sites & 18 & 15,437 \\
\hline
\end{tabular}

Mehran University Research Journal of Engineering \& Technology, Volume 36, No. 4, October, 2017 [p-ISSN: 0254-7821, e-ISSN: 2413-7219] 
converted into an off-street parking lot (which also requires access lanes, parking islands and driveways) it becomes 513 square feet. Thus, curbside parking utilizes land more efficiently as compared to off-street parking lots. In other words, if there are 2,000 parking spaces in a 23 acre off-street parking lot, the same amount of cars can be absorbed in just 8 acres of curbside parking, saving about 15 acres of urban land [3].

\subsection{Convenience and Easy Access}

Majority of the curbside parking sites in Lahore are located right outside their destination buildings. Therefore, drivers find it very easy to park their vehicles curbside. Driver interviews reveal that a significant majority (56\%) park their vehicles along the curb because of easy and quick access to their destinations and because of convenience during ingress and egress movementsof their vehicles [7].

\section{DISCUSSION}

Lahore is absorbing rapidly increased volumes of motorized transport modes, especially cars and motorcycles. Lahore's weak and inadequate public transport system is primarily to blame for the shift to cars and motorcycles. In contrast, cities all over the world are using good public transport to reduce the number of trips made by personalized transport [17].

Although parking spaces in Lahore are provided by various parking practices, including off-street covered parking, off-street parking lots, frontage parking, and parking plazas, the focus of the Punjab Government has been on the construction of the multi-storey parking plazas. In the government's opinion, these parking plazas would magically absorb the increased parking demand from the rise in cars and motorcycles. Khan [18] reports that the city government prefers parking plazas because they believe that some of the traffic congestion due to curbside parking could be eased by building parking plazas. According to a transport study [9], a total of 21 sites have been proposed for building parking plazas near various commercial areas at a cost of PKR 800 million (US\$7.6 million) per plaza.

TABLE 4. CONTRIBUTION OF CURBSIDE PARKING IN REVENUE GENERATION

\begin{tabular}{|c|c|c|}
\hline No. & Name of Curbside Parking Site & Revenue Per Annum (PKR Million) \\
\hline 1. & Ufone - HBL Office Davis Road & 0.684 \\
\hline 2. & Warid Office Empress Road & 0.945 \\
\hline 3. & SNGPL Office Gurumanget Road & 0.756 \\
\hline 4. & McDonalds Model Town Link Road & 0.435 \\
\hline 5. & Mobile Zone Gulberg & 2.46 \\
\hline 6. & Hafeez Center Main Boulevard & 0.396 \\
\hline 7. & Eden Heights Jail Road & 2.382 \\
\hline 8. & Warid Office Main Boulevard & 1.32 \\
\hline 9. & New AurigaComplex Main Boulevard & 1.152 \\
\hline & Average Revenue of 9 Sites & 413.568 \\
\hline
\end{tabular}

Mehran University Research Journal of Engineering \& Technology, Volume 36, No. 4, October, 2017 [p-ISSN: 0254-7821, e-ISSN: 2413-7219] 
In the absence of curbside parking management guidelines, parking spaces have been haphazardly located. For instance, some of the parking sites are approved near U-turns which create problems for turning vehicles. Non-existence of a framework for parking management has paved the way for politically influential people to intervene in the process; for example, some parking sites such as Chen one Hali Road Gulberg and Haji Camp Empress Road were removed by such influential people. As parking spaces are not marked on the ground, even at authorized parking sites, parking contractors often use more than one lane in pursuit of collecting maximum revenue.In some cases, contractors use sidewalksas parking spaces [19] Unfortunately, the absence of parking management guidelines is due to the lack of technical skills and expertise on the part of the authorities.

\section{Box-1 Curbside Parking Prohibitions [20]}

- In front of an entrance of an office building

- In front of an entrance to a hospital

- Within 20 meters of an intersections

- Upon that side of a street immediately adjacent to any school property

- Upon that side of the street and immediately adjacent to the frontage or flankage of any service station providing fuel for motor vehicles;

- $\quad$ within 30 meters of any intersection controlled by traffic signals

- Within 30 meters of any railway level crossing.

- Within the limits of a roundabout and within 20 meters on any approach street to a roundabout

- Immediately adjacent to an inner curb within a cul-de-sac, where a cul-de-sac is constructed with an inner and outer curb
Fixed parking price encourages longer parking duration and minimum turnover of parking spaces. However, good parking management is based on correctly pricing parking. For instance, Shoup [16] argues the "rightprice" for curbside parking can be determined based on a target occupancy of around $85 \%$. The prices should be kept higher where the demand is higher and vice versa.In order to increase efficiency, the price structure should be kept variable and adjusted for different time periods of a day and different days of a week. Furthermore, potential future demand should also influence parking prices, such as during the holidays [21]. Furthermore, the right price increases parking turnover, freeing up spaces and helping to bring more customers into the area whichmay not generate maximum revenue, depending on the price elasticityfluctuations. If prices are set for maximum revenue, then parking turnover might decrease. If parking is underpriced, it will cause overcrowded parking lots and street curbs, compelling some drivers to park on the sidewalks. Unfortunately, cars blocking sidewalks degrades life for the far greater number of pedestrians using the sidewalk. This performance pricing scheme has been successfully experimented in cities like Redwood, San Francisco, California and Mexico which continually adjust parking prices to match demand [1].

This paper shows that twice as many motorcycles need to be parked as compared to cars, and a parking management strategy cannot ignore motorcycle parking. Thus, it is necessary to adjust the price of motorcycle parking as well. For example, Barter [22] states that motorcycle parking is very efficient because motorcycles occupy less space than cars. According to him [22], about 5-6 motorcycles could be parked in a single car space. Thus, keeping in mind the factor of space consumption, the price of motorcycle parking should be one-sixth of the car parking price [22]. 
Parking is a coordinated effort of various government departments. Some are concerned with provision of off-street parking spaces, such as LDA, CDGL and TMAs. Others are responsible for authorizing parking sites such as Le-Park. Some departments care about traffic management, such as the Traffic Police, while other build new Parking Plazas such as TEPA. Another department namely LTC (Lahore Transport Company) provides public transport services but does not consider the effect on parking demand. The study shows that there is lack of coordination among the indicated departments right from the planning to the implementation of curbside parking spaces. Parking enforcement is currently the responsibility of traffic wardens, who are already overburdened in managing city traffic. The coordination for parking facilities in general, and curbside parking facilities in particular, needs serious consideration. According to de Cerreño [23], the integration is very necessaryamong agencies responsible for parking policy development, management, execution and adjudication. More specifically, there are 35 departments among which coordination should be encouraged [24]. This is especially needed to start regulating and collecting revenue from unauthorized parking sites since government agencies currently lack the capacity to bring unauthorized sites out of the illegal economy.

The viewpoint of different stakeholders involved in the process of parking can help manage curbside parking. According to Alam [25], parking management procedure should begin with the identification of various stakeholders. These stakeholders might include residents and employees who prefer parking close to their homes and workplaces respectively, businessmen who like parking to be in front of their doorstep, and developers who always want to make their projects profitable.
Although the CDGL has established the Le-Park to help fix the parking chaos, currently its main focus is only on revenue generation. The parking provisions approved by Le-Park are often opposed by City Traffic Police due to lack of coordination.

Based on pure geometry, parallel parking is considered to be the best parking option because it creates less hindrance to the flowing traffic in comparison with other angular parking arrangements (Table 5 where ' $x$ ' refers to number of vehicles parked at a fixed curb space in parallel parking arrangement). Sisiopiko [4] believes that whenever on-street parking is required, it should be proposed in parallel arrangement to minimize its adverse effect on moving trafficstream.

\section{CONCLUSION}

The subject of curbside parking is very important and wide ranging. It is very difficult to give specific proposals regarding parking because every type of area has different characteristics of land use, height restrictions, etc. The following points are pertinent for better curbside parking management.

The existing public transport system needs improvement in areas of efficiency, coverage, and affordability so that dependency on private modes is minimized. Greater public transit use will result in generation of less parking space demand throughout the city.

TABLE 5. COMPARISON OF PARKING ANGLE WITH VEHICLE PARKED AND TRAFFIC HINDRANCE [26-27]

\begin{tabular}{|c|c|c|}
\hline Parking Angle & $\begin{array}{c}\text { Number of Vehicles } \\
\text { Parked }\end{array}$ & $\begin{array}{c}\text { Degree of Traffic } \\
\text { Hindrance }\end{array}$ \\
\hline 0 & $\mathrm{X}$ & Very Less \\
\hline 30 & 1.2 times ' $\mathrm{X}$ ' & Less \\
\hline 45 & 1.6 times ' $\mathrm{X}$ ' & Medium \\
\hline 60 & 2.0 times ' $\mathrm{X}$ ' & High \\
\hline 90 & 2.4 times ' $\mathrm{X}$ ' & Very High \\
\hline
\end{tabular}

Mehran University Research Journal of Engineering \& Technology, Volume 36, No. 4, October, 2017 [p-ISSN: 0254-7821, e-ISSN: 2413-7219] 
A detailed feasibility study needs to be initiated to categorize permitted and prohibited parking areas keeping in mind safety and convenience. The viewpoint of various actors involved in the process of curbside parking (such as residents, businessmen, developers, employees, customers and students) must be taken into account. The recommendations of the feasibility study will pave the way for developing comprehensive parking management guidelines and regulations, which will subsequently help authorities to control existing and future parking areas.

Curbside parking not only causes problems but also provides benefits, such as revenue generation, parking supply, land use efficiency, convenience, and easy access. Solution do not lie in removal of parking from roads, but rather in its effective management in such a way that problems are minimized and benefits are maximized.

The existing parking price system is irrational and does not encourage efficient use of curb space. The parking price should be kept variable to achieve85\% occupancy rate. The proposed parking rates can be adjusted up or down once the desired occupancy rates are observed. Additionally, the price of motorcycle parking should be kept in proportion to the price of car parking. Since ratesetting is trial-and-error process, the exact parking prices cannot be determined without looking at the results. Once rates are in place, parking revenue should be kept in a separate account and a reasonable proportion should be returned to the site from where it is collected, generating acceptance among people for variable pricing. In conjunction with this, all unauthorized parking points should be brought under authorization umbrella to maximize revenue.

Finally, there is also a need to build capacity of the concerned authorities in managing curbside parking resources through trainings and workshops. There should be joint responsibility of a single department for parking management like Le-Park. It should also recruit parking enforcement inspectors for effective monitoring of violations.
To recapitulate, curbside parking is one of the key contributors in the supply of parking which is usually ignored while planning and designing. It is, therefore suggested that it should be given special attention at every stage of planning process. Due to range of advantages it offers to its users, its provision should be made in accordance with roper management measures.

\section{ACKNOWLEDGEMENT}

The authors would like to take this opportunity to thank Prof. Donald Shoup, Department of Urban Planning, University of California Los Angeles, USA, for, providing valuable guidance. Without Prof.Shoup’s personal input, this research paper would never have been completed. The authors are also thankful to Mr. Sheikh Abdur Rasheed, Mr. Todd Litman, Kamil Khan Mumtaz, Mr. Ahmad Rafay Alam, Mr. Iftikhar Mahbub and Mr. Ahsan Iqbal, for their help during the course of this research endeavor.

\section{REFERENCES}

[1] Shoup, D., "Parking Today", Volume 14, pp. 22-23, 2009.

[2] Zalewski, A.J., Buckley, S.M., and Weinberger, R., "Regulating Curb Space: Developing a Framework to Understand and Improve Curbside Management”,

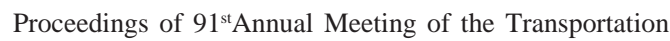
Research Board, Washington DC, 2011.

[3] Marshall, W., Garrick, N., and Hansen, G., "Reassessing On-Street Parking”, Transportation Research Record, Volume 2046, pp. 45-52, 2008.

[4] Sisiopiko, V.P., "On-Street Parking on State Roads", Proceedings of ITE International Conference, Chicago, Illinois, 2001.

[5] Box, P.C., "Curb Parking Findings Revisited", Transportation Research E-Circular, Urban Street Symposium, Dallas, Texas, 2000. 
[6] Shoup, D., “Cruising for Parking”, Transport Policy, Volume 13, No. 6, pp. 479-486, 2006.

Sabir, S., "Kerbside Parking Management in Lahore (Case Study of Gulberg Town)”, M.Sc Thesis, Department of City \& Regional Planning, University of Engineering \& Technology, Lahore, Pakistan, 2010.

Government of Pakistan, "Population and Housing Census of Pakistan”, Population Census Organization, Federal Bureau of Statistics, Government of Pakistan, 1998.

[9] Japan International Cooperative Agency, "Lahore Urban Transport Master Plan Study”, Government of the Punjab, Lahore, 2012.

[10] Ali, R., "Unplanned, Illegal Constructions Create parking Problems”, The News, Lahore, Pakistan, 2008.

[11] Urban Unit, "LDA Building and Zoning Regulations", Punjab Gazette, Lahore, 2007.

[12] Wordpress, "Meter Parking System at Mall Road Lahore", World Press, Lahore, Pakistan, 2009.

[13] Khan, R., "Public Space: LePark Accuses Traffic Police of Selective Action”, The Express Tribune, Lahore, Pakistan, 2013.

[14] Husnain, K., "CDGL Tough Talk on Illegal Parking Lots”, The Dawn, Lahore, Pakistan, 2011.

[15] NESPAK, “Integrated Master Plan of Lahore 2021”, LDA, Lahore, 2004.

[16] Shoup, D., "The High Cost of Free Parking”, Chapter 12, Planners Press, Chicago, 2005.
[17] CSE, “CSE's International Conference on Parking Reforms”, Centre for Science and Environment, New Delhi, India, 2011.

[18] Khan, R., "Road Congestion: City Govt Revives Proposal for Parking Plazas”, The Express Tribune, Lahore, Pakistan, 2012.

[19] Ahmad, S., "No Room for Pedestrians as Footpaths Become Parking Lots!”, The Nation, Lahore, Pakistan, 2012.

[20] Council of the City of London, "Traffic \& Parking Bylaw”, Council of the City of London, Canada, 2013.

[21] Pierce, G., Shoup, D., “Getting the Prices Right”,Journal of the American Planning Association, Volume 79, No. 1, pp. 67-81, 2013.

[22] Barter, P.A.,’Parking Policy in Asian Cities”, Asian Development Bank, Manila, Philippines, 2011.

[23] de Cerreño, A.L., "The Dynamics of On-Street Parking in Large Central Cities”, Rudin Center for Transportation Policy \& Management, New York, 2002.

[24] Urban Unit, "Seminar on Parking Issues and Remedies", Urban Unit, Lahore, Pakistan, 2012.

[25] Alam, A.R., "On Parking”,The Express Tribune, Lahore, Pakistan, 2012.

[26] Indian Institute of Technology, "Demonstration of Angle Parking”, Indian Institute of Technology, Bengal, India, 2007.

[27] Department of Transportation, “Angle Parking”, Traffic Division, Hampden City Council, Hampden, 2009. 